\title{
ISLAMISASI DAN KAITANNYA DENGAN HUBUNGAN SERANTAU MALAYSIA - INDONESIA
}

\author{
Mashitah Sulaiman \\ Mohammad Redzuan Othman
}

\begin{abstract}
The process of Islamisation is often considered as the driving force in initiating social change in the Malay communities. It is undeniable that mutual influence plays a role in the relationship of the Muslim communities in Malaysia and Indonesia with regards to way of life, beliefs, and thoughts. The relationships between the two regions are enhanced through mutual communication among Islamic scholars, through trade and other activities. This paper traces the roles of Islamic da'wah in the history of relationship between the Malay communities in the region during the Islamic Malay sultanate around the 1800s until the early 1900s. This paper also analyses the process of Islamisation in Malaysia and Indonesia and the approaches taken by the Islamic activists in both countries during the Islamic revival of the 1970s until the 1990s. Activities by the Islamic movement and actions that had given impacts on the development of culture and changes in thinking are also discussed.
\end{abstract}

\section{Pengenalan}

Gelombang kemasukan dan penerimaan Islam secara meluas di rantau ini merupakan peristiwa penting dalam sejarah Alam Melayu yang masih menjadi tanda tanya dalam kalangan sebahagian sejarawan. Walaupun kepercayaan pra-Islam masih diamalkan, namun tidak pun sampai tiga abad, Islam telah berjaya menggantikan budaya India yang telah berakar umbi sejak berabad-abad lamanya dalam masyarakat Melayu. Sejak abad kelima belas, Islam telah muncul sebagai ciri dan 
agama penting yang menyatukan dan menghubungkan masyarakat di Kepulauan Melayu dan hanya meletakkan budaya India sebagai sebahagian warisan sejarah lampau masyarakatnya.

Aktiviti penyebaran agama Islam membolehkan wujudnya jaringan ulama, tradisi intelektual serta amal Islami dan rantaian hubungan ini telah mendekatkan masyarakat Islam di rantau ini. Walaupun dipisahkan dengan jarak dan sempadan lautan, namun ciri budaya Melayu, bahasa dan ajaran tauhid mendekatkan mereka untuk beramal dengan ajaran Islam. Ciri-ciri kesatuan Islam yang bersandarkan tauhid dan amal Islami telah menjadikan masyarakat di Malaysia dan Indonesia yang sebahagian besar penduduknya kini beragama Islam sebagai satu ummah dengan jumlahnya terbesar di dunia pada hari ini.

\section{Aktiviti Pengislaman dan Jaringan Ulama di Alam Melayu}

Sejarah hubungan antara wilayah yang kini dikenali sebagai Malaysia dan Indonesia telah dikesan wujud sejak beratus-ratus tahun lamanya dalam kerajaan Srivijaya dan Majapahit, kesultanan Melayu Melaka, kerajaan Johor-Riau dan sebagainya semasa kerajaan-kerajaan ini menguasai Alam Melayu. ${ }^{1}$ Namun begitu, hubungan dan kerjasama serantau ini tergugat dengan kedatangan penjajah Portugis, Belanda dan British. Walaupun demikian, peranan Islam sebagai agama yang membentuk budaya dan cara hidup manusia masih menjadi faktor penghubung yang menguatkan pertalian persaudaraan dan aqidah antara masyarakat, khususnya orang Melayu Islam di rantau ini. ${ }^{2}$

Perjuangan menghidupkan semula cara hidup Islam bukanlah merupakan suatu fenomena baru di Malaysia dan Indonesia. Sejak awal zaman kemasukannya ke rantau ini, Islam telah menjadi teras yang menunjangi kehidupan masyarakat Melayu dalam pelbagai aspek dari segi politik, sosial dan budaya. Kesan penerimaan Islam dalam masyarakat Melayu dapat dilihat dalam beberapa aspek penting kehidupan mereka yang mengubah lanskap budaya, pemikiran, struktur politik dan pemerintah sehingga terkesan dari peringkat golongan atasan ke peringkat rakyat jelata. Lebih penting ialah hasil aktiviti dakwah Islam telah wujud satu rangkaian perhubungan manusia yang akrab antara para ulama, penuntut ilmu, pedagang dan masyarakat Islam di wilayah Malaysia dan Indonesia yang menjadikan wacana pemulihan dan kebangkitan Islam pada abad seterusnya semakin berperanan. ${ }^{3}$

Selain menjadikan Timur Tengah dan Haramayn (Makkah dan Madinah) sebagai tempat untuk mendalami pengajian Islam, beberapa kawasan di Malaysia seperti pondok dan madrasah di Kedah, Kelantan, Terengganu dan sebagainya turut menjadi pilihan para penuntut dan 
pendakwah dari Indonesia. ${ }^{4}$ Begitu juga sebaliknya, beberapa universiti, surau dan pesantren di Sumatra, Indonesia menjadi tempat untuk mempelajari pelbagai ilmu Islam bagi pelajar dari Tanah Melayu. Terdapat banyak contoh bagaimana tradisi keintelektualan Islam telah menggalakkan budaya menuntut ilmu sehingga masyarakat Melayu sanggup merantau merentasi sempadan dan wilayah, semata-mata untuk menuntut ilmu Islam, berdakwah dan beramal dengan ajarannya. ${ }^{5}$

Sejarah pengislaman masyarakat di Alam Melayu mencatatkan beberapa contoh jaringan dakwah Islam serantau pada peringkat awal. Kerajaan Melayu Melaka pernah muncul sebagai pusat kebudayaan dan penyebaran Islam pada abad ke-15. Selain masyarakat tempatan, terdapat ramai penuntut yang berasal dari pelbagai tempat di kepulauan Melayu yang datang belajar di Melaka. Setelah pulang ke tanah air, mereka berperanan sebagai pendakwah dan sesetengah daripada mereka turut menubuhkan pusat-pusat pendidikan Islam seperti, pondok dan pesantren di tempat masing-masing. Sunan Bonang dan Sunan Giri umpamanya, merupakan antara tokoh "wali Sembilan atau Songo' yang menubuhkan pesantren dan mengembangkan Islam di Kepulauan Jawa dikatakan pernah mengikuti pengajian agama di Pulau Upih, Melaka. ${ }^{6}$

Tertegaknya kerajaan Johor-Riau/Lingga merupakan satu lagi bukti yang jelas kebersamaan dan kesatuan serantau di antara wilayah Malaysia-Indonesia yang berpanjikan kepada pemerintahan bercirikan hukum Islam. Sebagaimana diceritakan oleh Raja Ali Haji dalam Tuhfat al-Nafis, bahawa kerajaan Johor-Riau/Lingga memiliki tradisi agama dan budaya ilmu yang sangat hebat. Malahan, keintelektualan Raja Ali Haji dalam ilmu agama dan politik pemerintahan juga telah diiktiraf di rantau ini. Pemikiran dan karya beliau seringkali dirujuk sehingga kini dalam pelbagai bidang agama, kesusasteraan dan politik. ${ }^{7} \mathrm{Hal}$ ini terbukti apabila semasa hayat beliau, Temenggung Abu Bakar telah menghantar beberapa orang kepercayaannya untuk meminta nasihat daripada Raja Ali Haji berkenaan hal ehwal kerajaan Johor. Malahan, Raja Ali Haji juga telah dijemput menjadi tetamu kehormat ketika pertabalan Temenggung Abu Bakar menjadi Sultan Johor pada tahun $1868 .^{8}$

Abdul Samad al-Jawi al-Palimbani, al-Raniri dan Haji Abdul Karim Amrullah adalah antara beberapa contoh dalam kalangan ulama yang memainkan peranan menghubungkan masyarakat Islam di rantau ini melalui aktiviti dakwah dan pengajian ilmu. Abdul Samad al-Jawi alPalimbani merupakan seorang ulama besar dan ahli sufi terkenal di Alam Melayu. Beliau tidak hanya dikenali dengan ilmu dan aktiviti dakwah di tanah kelahirannya Palembang, tetapi turut dikenali di Tanah Suci Makkah serta Madinah dan Kedah, di Semenanjung Malaysia. ${ }^{9}$ 
Ayah al-Palimbani, iaitu Syeikh Abdul Jalil bin Syeikh Abdul Wahhab bin Syeikh Ahmad Al-Mahdani merupakan ulama yang berasal dari Yaman yang dilantik menjadi Mufti negeri Kedah pada awal abad ke18. Manakala ibunya, Radin Ranti adalah seorang wanita Palembang yang dikahwini oleh Syeikh Abdul Jalil, yang sebelumnya menikahi Wan Zainab, seorang puteri kepada Dato' Sri Maharaja Dewa Kedah. Selain mempelajari ilmu tasawwuf daripada Syeikh Muhammad bin Samman, mendalami kitab-kitab tasawuf daripada Syeikh Abdul Rauf Singkel dan Samsuddin Al-Sumaterani, (di mana kedua-duanya berasal dari Acheh) ${ }_{1}^{10}$ Syeikh al-Palimbani juga mendapat pendidikan agama di Kedah dan Patani. ${ }^{11}$

Ketokohan al-Palimbani dalam bidang ilmu, penulisan dan dakwah tidak hanya dikenali di Haramayn, malahan di Alam Melayu khususnya di tanah airnya, Palembang dan Malaysia. Jasa al-Palimbani dalam bidang keintelektualan dan agama di Alam Melayu dengan mewariskan beberapa karyanya yang agung antaranya, Syar al-Salikin ila 'Ibadah Rabb ai-'Alamin dan Hidayah al-Salikin fi Suluk Maslak alMuttaqin. Al-Palimbani tidak hanya berperanan di tanah airnya, bahkan turut gugur syahid dalam peperangan mempertahankan Kedah dari serangan Siam pada tahun 1832. Seruan jihad bagi menentang Siam menyebabkan Sheikh Abdul Samad al-Palimbani bersama-sama dengan Syeikh Daud Fatani meninggalkan Makkah. Al-Palimbani telah dilantik sebagai panglima perang. Beliau ditangkap dan disula oleh tentera Siam serta kepalanya dipancung untuk dipersembahkan kepada Maharaja Siam. Beliau dikatakan disemadikan di Mukim Jenung, Chanaa iaitu, berhampiran dengan Pondok Bantrap. ${ }^{12}$

Sementara itu, seorang lagi tokoh sufi iaitu al-Raniri yang sejarah perjuangan dakwahnya diceritakan dalam sejarah kemasukan Islam ke negeri Kedah telah sampai ke negeri tersebut pada abad ke-17. Pada masa itu masih ramai masyarakat Melayu yang mengamalkan fahaman Hinduisme. Diceritakan bahawa Aceh telah menyerang Kedah bagi mengembalikan masyarakatnya kepada Islam. Namun begitu, atas usaha al-Raniri, kitabnya Sirat al-Mustaqim telah dihantar ke Kedah pada tahun 1640-an. Kitab ini menjelaskan asas-asas agama, peraturan dan undang-undang ibadat serta undang-undang perkahwinan. Hasil dakwah al-Raniri, Islam kembali berpengaruh dan berkembang di Kedah. Peranan yang dimainkan oleh al-Raniri ini sama pentingnya dengan peranan Abdullah al-Yamani, iaitu ulama yang pertama membawa Islam ke Kedah. ${ }^{13}$

Selain itu, Haji Abdul Karim Amrullah yang berasal dari Maninjau, Sumatera Barat pula dikenali kerana usahanya dalam mewujudkan jaringan ulama serantau pada sekitar awal abad ke-19. Beliau telah merantau ke beberapa buah negara antaranya, melawat Malaysia 
(dahulu dikenali sebagai Tanah Melayu) pada tahun 1916, ke Mesir dalam tahun 1926, di samping perjalanannya ke Makkah dalam rangka menuntut ilmu antara tahun 1894-1901 dan 1903-1906. Seterusnya beliau telah mengembara ke Tanah Jawa pada tahun 1917 dan 1925 dalam misi menggerakkan dan memperkuatkan semangat pembaharuannya untuk membangunkan kesedaran Islam dalam masyarakat Minangkabau. Tambahan pula, pada masa itu idea pembaharuan Islam atau gerakan Islah sedang bertiup kencang di Mesir, hasil cetusan gerakan yang dilakukan oleh Jalaluddin al Afghani, Muhammad Abduh, Rasyid Rida dan lainnya di Timur Tengah. Keadaan ini telah menguatkan keinginannya untuk melakukan pembaharuan terhadap masyarakatnya agar kembali kepada al-Qur'an dan Hadis. ${ }^{14}$

Situasi yang sama turut berlaku kepada masyarakat dan pemerintah Islam di Malaysia. Pusat pertumbuhan kebudayaan dan kerajaan Melayu Islam yang muncul di Indonesia menjadi tempat rujukan apabila timbul persoalan yang berkaitan tentang agama Islam, sama ada dalam kalangan masyarakat awam mahupun kerabat diraja. Sejarah Melayu pernah menyebut tentang kemusykilan berkaitan ilmu agama sehingga Sultan Mansur Shah (1459-1477), Sultan Kesultanan Melayu Melaka menitahkan Maulana Abu Bakar membawa sebuah kitab teologi dan tasawwuf, bertajuk Durr al-Manzum yang ditulis oleh gurunya, Abu Ishaq al-Shirazi ke istana Melaka. Atas titah baginda, buku tersebut telah dibawa ke istana Pasai untuk mendapatkan penjelasan, pemahaman dan tafsiran selanjutnya berkaitan agama sebelum dibawa semula ke Melaka bagi meneruskan pengajian baginda. Pada ketika itu, Pasai terkenal sebagai sebuah kerajaan yang terawal menerima Islam dan amat tersohor dalam aspek pengajian Islam dan kesusasteraan Melayu-Islam. ${ }^{15}$

Aktiviti dakwah dan keilmuan Islam telah menggalakkan hubungan masyarakat di Malaysia dan Indonesia. Namun begitu, apakah sebenarnya kekuatan yang mendorong tercetusnya hubungan yang akrab di antara masyarakat di rantau ini?. Terdapat beberapa faktor yang mengalakkan kewujudan hubungan dan jaringan antara ulama dan keintelektualan Islam di Nusantara, khususnya di antara wilayah Malaysia dan Indonesia. Pertama, ciri-ciri agama Islam yang bersifat agama dakwah yang disebarkan membantu menghubungkan masyarakat Melayu Islam di Kepulauan Melayu. Agama ini mengajak manusia agar melakukan kebaikan, dan menjauhi perkara-perkara yang membawa kemusnahan di samping mengenali pencipta dan pelaksanaan peranan manusia sebagai pemakmur muka bumi. Hal ini bersesuaian dengan tugasan Rasulullah SAW menyampaikan utusan daripada Allah SWT untuk kesejahteraan umat manusia. Ajaran ini menuntut usaha dalam mengajak sesama manusia melaksanakan 
tanggungjawab kepada tuhan, manusia dan makluk yang lain yang menjadi tugas utama pendakwah dan ulama di serata dunia termasuk berdakwah ke pelusuk Alam Melayu. ${ }^{16}$

Kedua, sifat Islam sebagai agama universal yang sesuai untuk semua tempat dan masa serta mudah difahami telah mendekatkan manusia dengan agama tersebut. Islam juga tidak membataskan sempadan geografi sesama manusia walau di mana juga berada, warna kulit dan latar belakang budaya menyebabkan tiada istilah diskriminasi, rasa tersisih dan disisihkan kerana manusia adalah sama disisi agama melainkan darjat taqwa dan ilmunya di dalam Islam. Islam juga menekankan persaudaraan atas dasar ukhuwah. Sekiranya manusia yang berbeza latarbelakang, budaya dan wilayah boleh dihubungkan melalui ajaran agama, apatah lagi kelompok manusia yang memiliki budaya dan bahasa yang sama seperti di Malaysia dan Indonesia. ${ }^{17}$

Ketiga, kedatangan Islam ke dalam masyarakat Melayu mencetuskan ledakan revolusi Ilmu. Tambahan pula, Islam juga menggalakkan penganutnya menuntut ilmu pengetahuan. Seruan dan galakan untuk manusia menuntut ilmu pengetahuan menjadi pendorong kepada pencinta ilmu Islam dari Malaysia dan Indonesia merantau untuk mempelajari Islam. Ulama dipandang tinggi dalam hierarki sosial Melayu sebagai pakar rujuk bagi sesuatu institusi Islam. Selain itu, setiap kawasan saling berhubungan dan bergantungan di antara satu sama lain di dalam menentukan sesuatu perkara yang berkaitan dengan Islam dan hukumnya. ${ }^{18}$

Keempat, wilayah Malaysia dan Indonesia mempunyai persamaan budaya dan bahasa. Perkongsian budaya dan cara hidup membantu mengeratkan pertalian serumpun di antara Malaysia dan Indonesia. Wilayah ini juga disatukan dengan satu rumpun bahasa yang sama di mana bahasa Melayu dengan menggunakan tulisan jawi digunakan secara meluas dalam penulisan karya dan kitab-kitab agama, sebagai bahasa pertuturan dan komunikasi dalam membina ketamadunan Melayu yang sangat tinggi. ${ }^{19}$

Kesatuan Keislaman-Melayu ini turut disumbangkan oleh faktor geografi yang mendekatkan kejiranan Malaysia-Indonesia yang pada suatu masa tiada batas sempadan yang memisahkan mereka, walaupun pada zahirnya dipisahkan oleh Selat Melaka. Namun begitu, para ulama, pedagang dan pencinta ilmu bebas untuk berulak alik dari Malaysia ke Indonesia dan sebaliknya tanpa batas sempadan geo-politik. Tidak sepertimana hari ini, akibat perjanjian Inggeris-Belanda 1824 telah menyebabkan kedua-dua negara Malaysia-Indonesia dipisahkan oleh sempadan politik negara bangsa yang memerlukan kebenaran oleh pihak berkuasa negara berkenaan untuk melepasi kawasan negara jiran. Walaupun demikian, hubungan strategik dan diplomatik antara 
kerajaan-kerajaan Melayu-Islam dan dengan Timur Tengah juga masih berterusan sejak bertapaknya Islam di rantau ini yang akhirnya memperkukuhkan kedudukan Islam dalam struktur budaya Melayu. Atas landasan ini, hubungan dan ikatan antara Malaysia-Indonesia masih bertaut erat dalam abad-abad seterusnya sehingga ke zaman komtemporari atas semangat persaudaraan seagama. ${ }^{20}$

\section{Kebangkitan Islam dan Kaitannya dengan Hubungan Serantau Malaysia-Indonesia, 1970-an - 1990-an}

Islam sentiasa menjadi faktor pencetus kepada perubahan sosial dalam masyarakat Islam apabila timbul kesedaran untuk kembali kepada Islam yang asal dan keadaan yang menimbulkan keresahan tentang situasi masyarakat yang semakin jauh dengan agama. Oleh itu, gelombang perubahan akan sentiasa muncul, malahan bumi Malaysia dan Indonesia turut menerima impak kebangkitan Islam, sama sepertimana yang melanda di Timur Tengah dengan peranan yang dimainkan oleh tokoh-tokoh tempatan yang utama dari kedua-dua buah negara. ${ }^{21}$

Sejak awal abad ke-20, orang Melayu di Nusantara telah terdedah dengan perkembangan yang berlaku di Timur Tengah. Apabila sistem pendidikan ala-Barat diperkenalkan oleh pihak British di Tanah Melayu bagi menggantikan sekolah-sekolah pondok tradisional, keadaan ini menimbulkan kegusaran dalam kalangan masyarakat Melayu tempatan tentang nasib dan masa depan pendidikan agama anak-anak mereka. ${ }^{22}$ Walau bagaimanapun, setelah idea pemulihan Islam atau Islah meresap masuk ke Tanah Melayu dan tersebar melalui pembukaan sistem madrasah moden dan penerbitan akhbar telah memberi kesedaran kepada masyarakat Melayu tentang kepentingan pendidikan agama moden. Gerakan Islah semakin mendapat tempat dalam kalangan Kaum Muda yang pernah mendapatkan pendidikan di Mesir atau terdedah kepada perkembangan yang berlaku di sana. Ini mendorong tuntutan terhadap perjuangan untuk menggembalikan kesucian Islam, pendidikan agama pada peringkat menengah dan pendidikan tinggi. Pemikiran Islah memperlihatkan pengaruh yang ketara dalam meningkatkan kesedaran pemikiran dan politik Melayu tentang kemunduran bangsa tersebut serta seruan supaya umat Islam melakukan perubahan dalaman bagi memperbaiki kelemahan mereka. ${ }^{23}$

Gerakan pembaharuan dalam masyarakat Melayu oleh Kaum Muda yang terpengaruh dengan gerakan di Mesir pimpinan Sheikh Muhammad Abduh dan Syed Jamal al-Din al-Afghani telah menggunakan pendekatan pendidikan madrasah yang mengikut model Mesir bagi menyebarkan pemikiran mereka. Penubuhan Madrasah al-Iqbal al-Islamiyah di Singapura di bawah naungan Raja Ali Kelana 
Riau telah menerokai sejarah pendidikan madrasah sekitar tahun 1908 dengan memperkenalkan pendekatan pendidikan moden yang mempelajari ilmu geografi, matematik, bahasa Melayu dan bahasa Inggeris, di samping pengajian agama Islam dan bahasa Arab. ${ }^{24}$ Model pendidikan Madrasah al-Iqbal kemudiannya telah menjadi ikutan kepada madrasah yang ditubuhkan di Tanah Melayu antaranya, Madrasah al-Hadi Melaka dan Madrasah al-Mashhor di Pulau Pinang. Madrasah-madrasah ini ditubuhkan oleh Sayyid Syeikh al-Hadi dengan matlamat untuk memberikan pendidikan agama secara moden kepada orang Melayu. ${ }^{25}$

Semasa Madrasah Mashoor ditadbir oleh Syeikh Abu Bakar al-Rafi', ramai pelajar lepasan madrasah ini telah dihantar untuk melanjutkan pengajian mereka ke Kaherah untuk mendalami ilmu Islam. ${ }^{26}$ Selain itu, melalui peranan yang dimainkan oleh Syeikh Tahir Jalaluddin, seorang ulama dan reformis kelahiran Tanah Minangkabau, Sumatera dengan dibantu oleh Sayyid Syeikh al-Hadi dan Haji Abbas Mohd. Taha, majalah al-Imam telah diterbitkan dengan mengambil pengaruh pemikiran majalah al-Manar dan menjadi manifestasi penyebaran pemikiran Islah Mesir ke dalam masyarakat Melayu di rantau ini. ${ }^{27}$

Kekuatan kesatuan keislaman-Melayu merupakan suatu yang sangat bermakna bagi kedua-dua negara, yang pada suatu ketika pernah menggagaskan kesatuan politik antara Tanah Melayu dengan Republik Indonesia seperti, Melayu Raya sumbangan idea oleh Ibrahim Yaakob dan Dr. Burhanuddin al-Helmi dari Tanah Melayu (iaitu Malaysia) dan gagasan Indonesia Raya hasil saranan oleh Muhammad Yamin dari Indonesia. ${ }^{28}$ Walaupun gagasan kesatuan politik serantau ini gagal diterima oleh orang Melayu di Tanah Melayu pada ketika itu, namun kesinambungan kesatuan berasaskan agama-bangsa ini semakin kuat dan erat semasa era kebangkitan semula Islam sekitar tahun 1970-an. Arus kebangkitan semula Islam yang bermula menjelang tahun 1970an tidak hanya berkembang di Timur Tengah, seperti Mesir, Iran dan Negara Barat, malahan turut bergema di Asia Tenggara, seperti Malaysia dan Indonesia. ${ }^{29}$

Gerakan Islam di Malaysia turut mengambil sikap dan pendekatan untuk saling belajar dan mempelajari daripada gerakan yang pernah mendahuluinya di bumi Islam yang lain dan melihat pergerakan mereka saling berkaitan, khususnya dalam menentukan misi dan perjalanan gerakan yang lebih berkesan kepada masyarakat. Ini termasuklah mengambil pengalaman daripada gerakan Islam di negara jirannya, seperti Indonesia. Hal ini dinyatakan oleh Presiden ABIM kedua, Anwar Ibrahim dalam Muktamar ABIM kesepuluh pada tahun 1981: 
Kebangkitan Islam di Malaysia tidaklah harus dilihat sebagai satu kebangkitan yang terpisah dari rangkaian gerakan Islam seluruhnya. Pengaruh dan pemikiran zaman lalu dan mutakhir telah menentukan saham besar terhadap perkembangan ini sehingga mampu dibentuk satu gerakan yang kukuh. Dasar gerakan seperti Ikhwanul Muslimin dan Jamaat Islami, kita jadikan pengalaman bersama. Pandangan tokoh-tokoh besar seperti Imam Hassan al-Banna, Maulana Abu 'Ala al-Maududi, Uthman dan Fodio dan lain-lain kita pelajari.

...Pengalaman gerakan Masyumi di Indonesia; Milli Selamat di Turki dan Revolusi Islam di Iran kita jadikan bahan kajian dan perbandingan. Kajian tidak harus pula dibatasi dengan pergerakan dan tokoh semasa, akan tetapi perlu ditimbulkan sikap menghormati ulama silam dan cuba menghayati pengajaran mereka untuk mengenali tokoh-tokoh seperti Hujjatul Islam Imam al-Ghazali, Ibn Khaldun, Ibn Sina, Shah Waliyullah Dahlawi, Muhammad Iqbal dan lain-lain. Ini adalah selaras dengan sikap kita bahawa gerakan yang dinamik dan berjaya adalah gerakan yang sifatnya terbuka dan bersedia mengkaji perkembangan sekitarnya. Akan tetapi kita harus sentiasa berasa dituntut untuk mengorak langkah dengan penuh hikmah terutama dalam menentukan kaedah dan haluan pergerakan. ${ }^{30}$

Kenyataan di atas juga jelas menunjukkan hubungan ABIM yang akrab dengan kepimpinan parti Masyumi di Indonesia dan tokoh yang dikaguminya ialah Muhammad Natsir atau lebih mesra disapa sebagai Pak Natsir. Selain Pak Natsir, terdapat juga beberapa orang tokoh Indonesia yang menjadi mentor kepada gerakan Islam di Malaysia, antaranya, Pak Hamka dan Dr. Ir. Imaduddin Abdul Rahim. Aliran pemikiran tokoh-tokoh ini telah banyak meresap ke dalam gerakan Islam di Malaysia, seperti ABIM. Bagaimanapun makalah ini hanya memberi tumpuan kepada dua tokoh utama iaitu Muhammad Natsir, Dr. Ir. Imaduddin Abdul Rahim serta beberapa sorotan tentang karya agung terkenal Indonesia yang membantu dalam pengisian kebangkitan Islam di Malaysia termasuk karya Hamka. ${ }^{31}$

Muhamad Natsir merupakan tokoh tidak asing lagi dalam kalangan pemimpin politik Islam dan aktivis gerakan Islam pada peringkat awal kebangkitan semula Islam era 1970-an dan 1980-an. Hubungan eratnya dengan Anwar Ibrahim telah mendekatkan Pak Natsir dengan Angkatan Belia Islam Malaysia (ABIM) yang menjadi pelopor kepada kebangkitan Islam di Malaysia. Melalui Pak Natsir juga ABIM mengikat hubungan mesra dengan Dewan Dakwah Islamiyah Indonesia (DDII) sehingga kini. ${ }^{32}$ Karya-karya dan buah fikiran beliau sentiasa menjadi panduan kepada ABIM untuk menyusun strategi dan menggerakkan aktiviti dakwahnya pada peringkat awal. Buku Figh 
al-Da'wah karya beliau yang merupakan satu-satunya buku berbahasa Melayu pada ketika itu yang membincangkan persoalan ilmu dakwah banyak membantu ABIM dalam mempergiatkan usaha dakwahnya. Atas permintaan tentang kepentingannya kepada organisasi dakwah, buku tersebut telah diterbitkan semula dalam versi tulisan jawi. ${ }^{33}$ Selain itu, satu lagi karya beliau iaitu, Capita Selecta menjadi rujukan dalam menghadapi cabaran politik, demokrasi dan pelbagai aliran pemikiran Barat, seperti sekularisme dan nasionalisme. Kritikan Natsir terhadap fahaman tersebut menjadi kekuatan kepada pendakwah dalam menghadapi lawan atau pihak yang didakwah secara ilmiah. ${ }^{34}$

Pengalaman Natsir yang luas dalam dakwah dan politik yang berteraskan Islam, yang mendahului organisasi-organisasi Islam di rantau ini turut memberi keyakinan kepada aktivis politik Islam di Malaysia bahawa politik Islam mampu pergi jauh dalam sistem demokrasi. Menurut Dato' Dr. Siddiq Fadzil, Mantan Presiden ABIM, Pak Natsir yang merupakan Mantan Menteri Penerangan dan pernah menjawat jawatan Perdana Menteri ini, telah mempopularkan istilah 'teistik demokrasi' atau demokrasi Islam yang sangat berbeza dengan demokrasi Barat. Ini memperlihatkan ketajaman pemikiran beliau dalam meneliti faham pemikiran Barat dan praktis Islam dalam konteks kontemporari. $^{35}$

Walaupun pengalaman beliau secara relatifnya singkat, namun cetusan idea dan pemikiran Pak Natsir amat berharga dalam konteks masyarakat plural di Malaysia. Selaku pemimpin Parti Masyumi, beliau merupakan orang pertama yang menolak gagasan politik Presiden Soekarno untuk menguburkan parti-parti yang wujud di Indonesia dan menerapkan konsep Demokrasi Terpimpin pada tahun 1956. Walaupun gagal mencapai cita-cita politiknya untuk mendirikan sebuah negara Islam di Indonesia, namun beliau tetap meneruskan agenda keIslamannya menerusi dakwah dengan penekanan dalam aspek manhaj dan uslubnya (cara dan pelaksanaannya). ${ }^{36}$

Natsir juga telah mendirikan wadah dakwah berbentuk yayasan dengan nama Dewan Dakwah Islamiyah Indonesia (DDII). Sebagai contoh beliau telah mengemukakan formula berikut yang menjadi kunci dalam mengharmonikan dakwah dan politik menerusi amalan al-akhlak al-karimah (akhlak mulia) seperti berikut: "Dengan akhlak mulia, seorang da'i akan dapat meresapi hati umat dan mampu memberi bimbingan maksima kepada umat. Dengan fatsoen politik, seorang politikus itu akan terhalang dari berperilaku menghalalkan segala cara" ${ }^{37}$

Dalam konteks ini, pendekatan yang digunakan oleh Pak Natsir telah dijadikan satu pandangan dan saranan yang diambil perhatian oleh aktivis gerakan Islam di Malaysia. Dato' Dr. Siddiq Fadzil, Presiden Wadah Pencerdasan Umat Malaysia (yang merupakan wadah bagi 
kesinambungan bekas aktivis ABIM) pernah mengkritik suasana politik semasa di Malaysia dengan pandangan bahawa:

Politik memang harus dimurnikan dengan membawa agama ke dalamnya, iaitu dengan berpolitik secara agama. Politik tidak harus diperlakukan secara pragmatic-utilitarian yang terpisah dari nilainilai keagamaan. Sikap dualistik: beragama secara murni, berpolitik secara permisif bukanlah sikap tauhidik seperti yang dituntut oleh agama. ${ }^{38}$

Dalam hal ini, dapat dilihat kesatuan idea antara kedua-dua pemimpin bahawa politik Islam hanya dapat dibentuk sekiranya pemimpinnya mengamalkan akhlak yang mulia dan sekiranya peminggiran aspek agama dalam politik berlaku tindakan tersebut akan menghancurkan masa depan ummah. ${ }^{39}$

Selain itu, hasil kerjasama dan hubungan dua hala antara ABIMDDII, didapati terdapat persamaan pendekatan antara kedua-dua organisasi dakwah ini di mana wujudnya penyatuan antara golongan intelektual dan ulamak dalam organisasi yang disertai oleh Pak Natsir dan ABIM, khususnya pada peringkat awal sekitar dan lewat 1970-an dengan tumpuan diberikan dalam aspek dakwah dan pendidikan. ${ }^{40}$ Buah fikiran Natsir juga telah dimanfaatkan oleh kepimpinan ABIM ketika berhadapan dengan saat getir bagi menyelamatkan Parti Islam Se-Malaysia yang dilanda krisis akibat kalah teruk dalam pilihan raya tahun 1978 dan kemerosotan imej ABIM setelah kemasukan Anwar ke dalam UMNO dan kerajaan pimpinan Mahathir. ${ }^{41}$ Dalam hubungan ini, benarlah kata Mohamad Roem bahwa Natsir adalah "hati nurani umat" dan kehadiran beliau memberi kesan bukan sahaja kepada gerakan Islam di Indonesia dan Malaysia bahkan Dunia Islam amnya. ${ }^{42}$

Pada awal 1970-an, Imaduddin Abdul Rahim, pensyarah kejuruteraan rakyat Indonesia dari Institut Teknologi Bandung yang terkenal sebagai pusat kegiatan politik dan dakwah Islamiah bagi pelajar di Indonesia, telah menjadi tenaga pengajar di Institut Teknologi Kebangsaaan (ITK) yang kini dikenali sebagai Universiti Teknologi Malaysia (UTM) di Kuala Lumpur. Semasa di Malaysia, beliau telah melatih mahasiswa sebagai kader-kader dakwah dengan nama Latihan Kader Dakwah (LKD) yang selanjutnya ditukar kepada Latihan Mujahid Dakwah (LMD). Pengisian dan latihan kepimpinan yang digunakan oleh Imaduddin amat berkesan dalam membangkitkan kesedaran untuk memberi komitmen yang tinggi dengan kefahaman tentang keperluan dalam perjuangan dalam kalangan pelajar di universiti tempatan. ${ }^{43}$

Walau bagaimanapun, wujud juga beberapa perkara yang kurang sesuai dalam konteks dakwah di Malaysia yang diketengahkan 
oleh beliau. Namun begitu, aliran pemikiran dan pendekatan keras yang diterapkan oleh beliau masih terkawal, lantaran dasar saling menghormati dan memaafi yang menjadi amalan dalam gerakan Islam, terutamanya ABIM. Atas permintaan pelajar, program ini merebak dari ITK ke IPT yang lain, seperti Institut Teknologi Mara (kini dikenali sebagai Universiti Teknologi Mara), Universiti Kebangsaan Malaysia, Universiti Pertanian Malaysia (kini dikenali sebagai Universiti Putra Malaysia) dan Universiti Malaya. Walaupun Imaduddin telah pulang ke Bandung setelah tamat perkhidmatannya dengan UTM pada tahun 1973, namun beliau kerap dijemput oleh pelbagai organisasi untuk mengadakan latihan dakwah. Kehadiran beliau yang membawa pendekatan dakwah yang tersusun dan orientasi kesedaran Islam secara menyeluruh berjaya memberi dimensi baru dalam program berbentuk latihan kepimpinan di Malaysia. ${ }^{44}$

Penyertaan tokoh-tokoh agama dan intelektual Indonesia dalam dakwah dan pendidikan berterusan dalam dekad ini. Beberapa cendikiawan Indonesia turut menyumbang sebagai ahli akademik ketika Malaysia mula mengembangkan pusat pengajian Islamnya ke tahap pengajian tinggi antaranya, O.K. Rahmat di Yayasan Pengajian Tinggi Islam, Nilam Puri, Kelantan yang kemudian menyambungkan perkhidmatannya di Universiti Sains Malaysia, Pulau Pinang, Dr. Hassan Langgulung menjadi tenaga pengajar di Fakulti Pendidikan, Universiti Kebangsaan Malaysia (UKM) yang kemudian menyambung perkhidmatannya di Universiti Islam Antarabangsa, Sidi Gazalba dan Mukhtar Lintang berbakti di Fakulti Pengajian Islam, UKM.45

Dalam usaha memahami Islam dan melaksanakan misi dakwah di Malaysia, gerakan Islam ini banyak merujuk kepada buku-buku dan karya-karya yang didatangkan dari negara yang telah melalui proses tersebut seperti Mesir, Pakistan dan Indonesia. Antara buku-buku yang dibawa dari Indonesia ialah Tafsir al-Azhar karangan Hamka dan beberapa karya beliau seperti, Sejarah Umat Islam, Falsafah Hidup dan Tasawuf Moden. Hamka atau nama sebenarnya Haji Abdul Malik Karim Amrullah dipanggil sebagai Buya amat dikenali sebagai ulama, pendakwah dan sasterawan unggul di Malaysia. Keakrabannya dengan Malaysia digambarkan daripada pengakuan beliau:

Sambutan ke atas diri saya, manusia yang dha'if ini, dari rakyat di kedua negara itu, sama mengharukan saya, kerana cinta saya kepada rakyat di kedua negara itu pun sama, tidak berlebih tidak berkurang dan tidak berat sebelah. Cinta saya menghadapi rakyat di Ujung Pandang sama dengan cinta menghadapi rakyat di Kota Kinabalu. Mahasiswa mengerumuni saya di Universiti Kebangsaan meminta tandatangan sama dengan kerumunan mereka di Universiti Gadjah Mada. Membaca khutbah Jumaat di Masjid Negara di Kuala Lumpur 
sama membaca khutbah di Masjid al-Azhar Jakarta. Berziarah di Slembah Indah Sri Menanti sama dengan pulang ke Batu Sangkar. Dan semua, saya hadapi dengan bahasa yang satu. ${ }^{46}$

Hamka yang juga merupakan mantan Presiden Majlis Ulama Indonesia (MUI) dan Penasihat Muhammadiyah Indonesia amat dekat dengan masyarakat Melayu Islam kerana sentuhan tintanya yang menyentuh jiwa tentang tujuan hidup sebagai Muslim, kepentingan akhlak mulia, perjuangan bahasa Melayu-Jawi dan kepentingan iman dan budi. Hamka juga menyakini bahawa Islamlah yang mempengaruhi kebangkitan Islam di Indonesia dan Alam Melayu umumnya. Islam menjadi teras kekuatan Melayu dan alat yang menyatukan bangsa. Sepanjang hayatnya, Hamka telah meninggalkan khazanah ilmu yang begitu besar sumbangannya kepada umat Islam daripada sejumlah 118 buah buku. ${ }^{47}$ Selain ABIM, Tafsir karangan Hamka ini masih dijadikan bahan usrah oleh sesetengah organisasi dakwah dan gerakan Islam di Malaysia seperti, Parti Islam Se-Malaysia dan Jemaah Islah Malaysia yang kini dikenali sebagai IKRAM Malaysia. ${ }^{48}$

Selain ketokohan pemikir dan aktivis Islam, keakraban hubungan antara Malaysia dan Indonesia turut disumbangkan oleh perkongsian bersama antara organisasi Islam di kedua-dua negara. Beberapa siri latihan dan program usahasama atau kerjasama turut dijalankan oleh organisasi dakwah Bukan Kerajaan (Non-Governmental Organization atau NGO) Malaysia dan Indonesia. ${ }^{49}$ Sejak sekian lama ahli-ahli politik, pejuang-pejuang kebangsaan serta tokoh-tokoh kesusasteraan Melayu sering menjadikan Indonesia sebagai rakan dalam memberikan bimbingan dan dorongan termasuklah dalam hal yang berkaitan dengan keagamaan. Pada peringkat awal gelombang kesedaran Islam dalam kalangan pelajar-pelajar universiti digerakkan di kampus, Persatuan Kebangsaan Pelajar Islam Malaysia (PKPIM) dan ABIM telah mengadakan program usahasama dan latihan perkaderan dengan Himpunan Mahasiswa Islam (HMI). HMI merupakan gerakan mahasiswa Islam terawal dan tertua di Indonesia dan di rantau ini yang ditubuhkan pada tahun 1947 di Jogyakarta. ${ }^{50}$

Antara perkara yang dimanfatkan oleh ABIM ialah cara mengendalikan gerakan, pelaksanaan program seperti bengkel dan latihan, khidmat masyarakat untuk membangkitkan kesedaran dan memberi tumpuan dalam khidmat masyarakat yang bermatlamatkan Islam. HMI juga membantu ABIM dan PKPIM menganjurkan beberapa lawatan dan latihan dakwah ke Jakarta dan Bandung yang merupakan pusat kebangkitan semula Islam dalam kalangan pelajar di Indonesia. ${ }^{51}$ Pengalaman HMI telah dimanfaatkan oleh pemimpin ABIM semasa di Jakarta dan Bandung dalam merumuskan hujah-hujah intelektual 
untuk menyokong seruan mereka agar Islam dijadikan cara hidup di samping bersedia menghadapi kumpulan sosialis dan nasionalis di universiti dan pihak kerajaan. ${ }^{52}$

Pertalian dan hubungan yang saling mempengaruhi turut berlaku dalam membentuk budaya hidup keislaman dalam masyarakat di kedua-dua negara. Pada peringkat awal kebangkitan Islam di Malaysia 1970-an, budaya memakai tudung amat asing dalam kalangan orang Melayu tidak kiralah di bandar mahupun di desa. Malahan, tidak keterlaluan sekiranya dikatakan ABIM sebagai gerakan Islam yang bermula di kampus Universiti Malaya telah mencetuskan idea kreatif tudung dan evolusi pemakaian tudung dalam kalangan wanita Islam sehingga mereka digelar sebagai 'orang dakwah'. ${ }^{53} \mathrm{Hal}$ ini dijelaskan sendiri oleh Presiden Pertama ABIM, Razali Nawawi tentang bagaimana beliau telah menyarankan agar muslimah ABIM mencipta 'satu jenis pakaian' yang menepati kehendak syariah. ${ }^{54}$ Menjelang pertengahan 1980-an kebanyakan wanita Melayu memakai mini telekung, tidak kurang juga yang berhijab dan mengenakan pakaian yang labuh sehingga yang kelihatan hanyalah tangan serta jubah yang menutup seluruh tubuh badan. ${ }^{55}$ Kecenderungan memakai tudung yang diperkenalkan di Malaysia pada awal 1970-an telah berkembang dan popular di Indonesia sekitar 1980-an sehingga negara tersebut kini berjaya menjuarai industri busana muslimah dan budaya bertudung era kontemporari yang sangat dikagumi di rantau ini. ${ }^{56}$

Minat terhadap irama keislaman atau nasyid menjadi begitu popular di Malaysia dan Indonesia dan pernah menjadi satu fenomena dalam masyarakat pada suatu ketika dahulu sekitar tahun 1990-an. Irama nasyid yang bermula di Malaysia sejak tahun 1970-an dianggap sebagai hiburan alternatif dengan pilihan terhad. Pada ketika itu, lagulagu nasyid di Malaysia dikuasai oleh Orkes Gambus al-Suraya dari Indonesia dengan lagunya yang terkenal Selimut Putih dendangan ibu Atikah Rahman. ${ }^{57}$ Kumpulan al-Mizan merupakan kumpulan nasyid pertama di Malaysia dan Singapura yang popular pada tahun 1980-an. Kumpulan ini telah menerbitkan album di atas inisiatif yang dimulakan oleh Warner Music Malaysia. Selain itu, turut muncul kumpulan nasyid Jawaher dan irama nasyid solo oleh Ahmadi Hassan. Kerancakan irama nasyid bermula dengan penganjuran pertandingan nasyid di peringkat kebangsaan yang dianjurkan oleh Radio Televisyen Malaysia (RTM). Pada ketika itu telah muncul beberapa kumpulan nasyid Darul Arqam iaitu, Nada Murni dan The Zikr yang menjadi perintis irama nasyid dengan tidak menggunakan alat muzik yang bertali dan tanpa penyertaan penasyid wanita. ${ }^{58}$

Sejak tahun 1991 Bahagian Hal-Ehwal Islam (BHEAIS) Jabatan Perdana Menteri Malaysia menganjurkan Festival Nasyid Kebangsaan 
diikuti dengan penganjurannya di peringkat MABIMS (ASEAN) di Kuala Lumpur pada tahun 1996. Pada tahun yang sama juga bermulanya era kegemilangan industri nasyid di Malaysia apabila kumpulan Raihan dengan albumnya "Puji-pujian" terbitan Warner Music Malaysia berjaya memecahkan rekod penjualan album terlaris dalam sejarah dunia muzik Malaysia dengan jualan hampir 700,000 unit. Kumpulan Raihan merupakan perintis zaman kegemilangan nasyid kontemporari di Malaysia yang turut mendapat sambutan hangat di Indonesia, Singapura Brunei dan Afrika Selatan. ${ }^{59}$

Sejak itu, banyak kumpulan nasyid telah muncul di Malaysia dengan pelbagai aliran muzik dari pop, hip-hop, rock yang semakin terbuka kepada penggunaan alat muzik moden yang bertali. Tema lagu-lagu nasyid turut berubah daripada lagu yang bercorak nasihat dan ketuhanan kepada membicarakan soal cinta dan dunia remaja serta pujian terhadap wanita solehah. Sehingga tahun 2008, terdapat lebih daripada 40 kumpulan nasyid yang aktif, manakala pada tahun 2005 seramai 120 individu dan kumpulan yang bergabung di bawah Persatuan Penggiat Nasyid (PIN). Genre nasyid telah mendapat pengiktirafan di Malaysia apabila disenaraikan dalam kategori khusus dalam Anugerah Industri Muzik Malaysia (AIM), Anugerah Album Nasyid Popular di Radio Era sebagai anugerah tahunan, sementara kategori Anugerah Artis Nasyid Popular dipertandingkan dalam Anugerah Bintang Popular Berita Harian. ${ }^{60}$

Pada hari ini irama nasyid di Malaysia telah mencapai tahap global apabila kumpulan-kumpulan nasyid negara telah berjaya mengadakan persembahan di peringkat antarabangsa. Malahan, kehadiran penyanyipenyanyi nasyid kontemporari antarabangsa seperti Cat Steven, Imad, Maher Zain, Irfan Makki, Zain Bhika, Sami Yusuf dan lain-lain yang mewarnai persada nasyid tempatan lebih mendapat sambutan hangat di Malaysia berbanding di tanah air sendiri. Sesetengah penyanyi nasyid solo seperti, Maher Zain dan Imad turut mendendangkan nasyid dalam bahasa Melayu bagi menarik minat sebahagian besar peminat mereka di Malaysia. Pada 30 April 2011 Malaysia telah menjadi tuan rumah penganjuran konsert Islamic Songs Festival ke-2 yang bertempat di Dewan Pleno, Pusat Persidangan Kuala Lumpur (KLCC). Festival ini disertai oleh 14 artis nasyid pelbagai negara di seluruh dunia dari benua Asia, Afrika, Amerika Selatan, Eropah, Amerika Utara, Asia Barat dan Oceania. Penganjuran ini merupakan satu lagi episod bersejarah dalam industri muzik amnya dan nasyid di Malaysia khususnya. ${ }^{61}$

Berbanding dengan Malaysia, industri nasyid kontemporari di Indonesia dikenali sejak pertengahan tahun 1980-an. Walaupun menjadi hiburan alternatif yang berkembang di sekolah tinggi dan universiti, namun nasyid telah menjadi pilihan golongan intelektual dan secara 
perlahan-lahan berkembang di luar lingkungan kampus. Sebelumnya, iaitu pada akhir tahun 1970-an terdapat kumpulan Bimbo yang berasal dari Bandung menerbitkan album Kasidah Kisah 25 Nabi. Menurut Alamsyah Agus, Ketua Umum Persatuan Nasyid Nusantara, nasyid hanya menjadi halwa telinga menjelang bulan Ramadan sehingga mendapat julukan "muzik ramadhan".$^{62}$ A pabila tamat bulan Ramadhan maka irama nasyid akan jarang didengari kecuali pada hari kebesaran Islam sahaja. Menjelang bulan Ramadan pelbagai festival nasyid, pertandingan dan pertunjukan yang hampir mustahil diadakan di bulan-bulan lain. Sehinggalah menjelang akhir tahun 1990-an, nasyid mula dikenali secara meluas oleh masyarakat dengan alunan berunsur nasihat, kisah-kisah para nabi dan tema ketuhanan. ${ }^{63}$

Tidak dinafikan bahawa kumpulan Raihan yang popular dengan album "Puji-pujian" dari Malaysia memiliki peminatnya yang tersendiri di Indonesia. Kemunculan kumpulan Raihan banyak mempengaruhi peningkatan minat masyarakat Indonesia terhadap nasyid dan kemajuan industri muzik Islam di negara tersebut. ${ }^{64}$ Sejak itu, muncul beberapa kumpulan, seperti Qatrunnada, Senandung Nasyid dan Snada dengan lirik keagamaan dan irama pop. Snada, iaitu singkatan dari Senandung Nasyid dan Dakwah, lahir dari satu persepakatan antara beberapa mahasiswa Universitas Indonesia. Mereka terdiri daripada Iqbal, Teddy, Lukman, Erwin, Ikhsan, dan Agus Alamsyah. Salah sebuah stesyen televisyen swasta juga turut mengambil inisiatif menganjurkan Festival Nasyid Indonesia dan Festival NTQ (Nasyid, Tausiyah dan Qiroah) yang kebanyakan pesertanya masih lagi didominasi oleh kaum Adam. ${ }^{65}$ Mengambil kira faktor keluasan wilayah Indonesia, sehingga kini terdapat lebih kurang 1500 pasukan nasyid di seluruh Indonesia. ${ }^{66}$

Kumpulan yang mewarnai persada nasyid Indonesia kini terdiri daripada Opick, Qatrunada, Haddad Alwi, Snada, Saudara Persaudaraan, Izatul Islam, Asyabab, Harmoni Voice, Bijak, Sam Abdullah, The Fikr, MQ Voice, Debu, Savana, dan lainnya. Keunikan kumpulan nasyid Indonesia ialah terdapat penyertaan warga Eropah yang mampu mendendangkan nasyid pelbagai bahasa, khususnya dalam bahasa ibunda Indonesia. Contohnya, Kumpulan Debu yang ditubuhkan pada tahun 2001 dianggotai oleh 12 ahli yang mempunyai kebolehan memainkan alat-alat muzik dari Timur dan Barat yang mempersonakan dengan keindahan gabungan gesekan viola, paluan rebana, gambus, gendang tabla, gitar flamenco dan bass elektrik. Mereka memperkenalkan irama "World Music" dan senikata lagu-lagu adalah dalam bahasa Indonesia, Inggeris dan Arab. Keunikan kumpulan yang menetap di Indonesia ini ialah, sepuluh daripada ahli kumpulan tersebut termasuk penyanyi utama yang merangkap ketua kumpulan iaitu, Mustafa Daood adalah berbangsa kulit putih dan berasal dari Amerika Syarikat. ${ }^{67}$ 
Menyingkap tentang hubungan dan kerjasama antara organisasi gerakan Islam di Malaysia dan Indonesia semasa fasa awal era kebangkitan semula Islam pada tahun 1970-1990-an dapat disimpulkan bahawa pertama, gerakan mahasiswa dan belia Islam di Malaysia khususnya, PKPIM dan ABIM mendapat suntikan daripada gerakangerakan yang mendahuluinya di negara lain bagi mengisi ruang kesedaran agama dengan pembinaan kekuatan dalaman iaitu, tarbiyah, kefahaman ilmu dakwah, kemahiran melakukan strategi dakwah dan kekuatan intelektual. Antara pertubuhan awal Indonesia yang membina jaringan kerjasama dengan gerakan Islam di Malaysia ialah HMI, Parti Masyumi dan DDII serta hubungan dengan individu tertentu yang mewakili Muhammadiyah. ${ }^{6}$

Kedua, keakraban hubungan Anwar Ibrahim dengan pemimpinpemimpin gerakan dan pertubuhan Islam di Indonesia dan negaranegara Islam membantu perkongsian kepakaran, idea dan saling bertukar-tukar pandangan yang memberi kesan kepada pewarnaan aksi politik dan usaha dakwah dalam ABIM (di peringkat organisasi) serta individu-individu gerakan Islam dalam mengisi proses Islamisasi di Malaysia pada tahun 1980-an. ${ }^{69}$

Ketiga, situasi kesedaran Islam di kedua-dua negara mempunyai kekuatan dan kelemahan masing-masing. Oleh itu, segala perubahan yang berlaku di sesebuah negara memberi kesan kepada negara jirannya dan berlakunya elemen saling mempengaruhi antara satu dengan yang lain. Ini dapat dilihat menerusi fenomena pemakaian tudung dalam kalangan wanita yang dievolusikan di Malaysia sekitar awal tahun 1970-an yang kemudiannya semakin popular di Indonesia, malahan Indonesia kini terkehadapan dalam industri tudung dan busana muslimah. Corak dan fesyen busana muslimah di Malaysia pula banyak dipengaruhi oleh pengaruh semasa fesyen busana yang terdapat di negara tersebut. ${ }^{70}$ Begitu juga dengan irama nasyid kontemporari yang semakin berkembang di Malaysia sejak tahun 1990-an dan turut mendapat perhatian dalam masyarakat Islam di Indonesia. ${ }^{71}$

\section{Kesimpulan}

Sejarah membuktikan keakraban hubungan serantau Malaysia dan Indonesia melalui aktiviti keagamaan dan kerohanian. Kesatuan Melayu-Islam ini dipupuk atas persamaan budaya, bahasa dan agama. Walaupun dipisahkan oleh Selat Melaka dan sempadan geografi, namun hubungan antara Malaysia dan Indonesia tidak mungkin dileraikan. Sebagai sebuah kawasan yang dihuni oleh sebahagian besar penganut Islam, ciri-ciri kebudayaan Islam dengan beberapa persamaan dan perbezaan budaya Melayu dan ciri kepulauannya amat terserlah dan 
masih utuh menyatukan umat Melayu Islam di rantau ini. Unsur persamaan dan kesatuan Islam ini telah mendekatkan individu Islam, jaringan ulama, karya intelektual, pertubuhan dan organisasi Islam dengan matlamat menyuburkan dan mendekatkan masyarakat Melayu terhadap kefahaman Islam. Walau bagaimanapun, dalam beberapa isu yang berkaitan Islam, pendirian masyarakat dan intelektual muslim di kedua-dua buah negara mungkin berbeza, namun atas semangat serumpun Melayu-Islam, dasar persefahaman dan toleransi Malaysia dan Indonesia masih menjadi rakan akrab dalam banyak perkara.

Keakraban hubungan antara Malaysia dan Indonesia membantu dalam proses perkembangan Islam, khususnya semasa era kebangkitan semula Islam pada tahun 1970-an hingga kini. Perkongsian maklumat, pengalaman dan hubungan intektual di antara organisasi Islam di kedua-dua buah negara dibina atas semangat untuk menyemarakkan kesedaran masyarakat terhadap amalan dan kefahaman Islam secara menyeluruh. Dalam aspek pembinaan Islamic cultural atau Islam dalam bentuk pembinaan budaya, kedua-dua negara saling memanfaatkan keindahan dan kreativiti kesenian berpakaian dan irama muzik secara Islam bagi manfaat masyarakat Melayu serantau. Keadaan ini telah mempengaruhi perkembangan industri tudung dan fesyen busana Muslimah serta industri irama nasyid yang semakin mendapat tempat dalam kalangan umat Islam di kedua-dua buah negara.

\section{Nota}

Frederik Holst, “(Dis-) Connected History: The Indonesia-Malaysia Relationship" dalam Eva Streifeneder, Antje Missbach (eds.), Indonesia - The Presence of the Past, A festshrift in honour of Ingrid Wessel, Berlin: regiospectra verlag, 2007, hlm. 328.

2 Menurut M.A. Rauf, walaupun penjajah Portugis di Melaka bertindak zalim dengan memusnahkan masjid dan pusara diraja untuk dijadikan bahan asas dalam pembinaan istana dan gereja katolik, namun tindakan ini tidak menghalang proses pengislaman yang pesat dalam kalangan masyarakat Melayu di Semenanjung Tanah Melayu. Seterusnya, Belanda yang mengambilalih pemerintahan Portugis di Melaka dan kepulauan Indonesia amat mementingkan keuntungan ekonomi di jajahan taklukannya dan turut memberi tumpuan kepada aktiviti kristianisasi bagi menghapuskan pengaruh Islam dalam masyarakat Indonesia. Kehadiran penjajah British memberi kesan kepada usaha pensekularan politik pemerintahan dan institusi agama, serta pelaksanaan sistem kapitalis yang memonopoli hasil bumi masyarakat tempatan. Kekayaan sumber asli dan kegiatan ekonomi didominasi oleh pendatang asing dari Barat dan Cina menyebabkan kepentingan masyarakat tempatan khususnya, orang Melayu terpinggir. Implikasinya, wujud perbezaan yang ketara antara antara bandar dan luar bandar yang kebanyakannya dihuni oleh 
masyarakat Melayu. Orang Melayu hidup terpencil di kawasan kampung dan menjalani kehidupan yang statik tanpa banyak perubahan. Mereka lebih menyukai persekitaran yang damai, lebih bersikap konservatif serta tidak menyukai inovasi atau perubahan drastik terhadap tradisi (mudah merasa selesa dengan amalan yang sedia ada) dan terdapat juga sebahagiannya yang berpegang dengan kepercayaan karut dan khurafat. Walaupun demikian, masyarakat Melayu masih berpegang teguh dengan amalan Islam seperti menunaikan haji di Makkah, meneruskan pengajian tentang Islam sama ada di rantau ini mahupun ke Makkah dan berterusan menerima pengaruh daripada aliran perubahan yang didatangkan dari Mesir seperti, pengaruh pemikiran Muhammad Abduh dan Rashid Rida. Walaupun kedatangan penjajah berusaha menghapuskan identiti agama masyarakat Melayu, namun Islam memainkan peranan yang penting dalam kesinambungan identiti masyarakat Melayu di rantau ini. Lihat, Rauf, M.A., A Brief History of Islam With Special Reference To Malaya, Kuala Lumpur: Oxford University Press, 1964, hlm. 92-93.

Sebagai sebuah masyarakat yang dinamik, penyertaan masyarakat Islam di Alam Melayu dalam jaringan hubungan intelektual pada peringkat serantau dan antarabangsa telah menjadi amalan yang masih berterusan sejak berabad-abad lamanya sehingga pada hari ini. Kesan pembangunan teknologi dan ekonomi telah meningkatkan lagi jaringan hubungan dalam kalangan masyarakat Islam dengan dunia luar. Pelbagai rujukan ilmiah dan kajian berkenaan hubungan ini telah dilakukan oleh sarjana tempatan dan Barat seperti, Azyumardi, Howard Federspiel dan Johan H. Meuleman. Lihat, Azyumardi Azra, "Hadhrami Scholars in the MalayIndonesian Diaspora: A Preliminary Study of Sayyid 'Uthman", Studia Islamika 2, No. 2 (April-June 1995): 1-33; Azyumardi Azra, The Origins of Islamic Reformism in Southeast Asia: Networks of Malay-Indonesian and Middle Eastern 'Ulama' in the Seventeenth and Eighteenth Centuries, Australia: Allen \& Unwin, 2004, hlm. 2-3; Federspiel, H. M., "Contemporary Southeast Asian Muslim Intellectuals: An Examination of the Sources for Their Concepts and Intellectual Contructs", in Islam in The Era of Globalization, Muslim Attitudes towards Modernity and Identity, edited by Johan Hendrik Meuleman, London and New York: Routledge Curzon, 2002, hlm. 327350; Meuleman, Johan H., "The History of Islam in Southeast Asia: Some Questions and Debates", in Islam in Southeast Asia: Political, Social and Strategic Challenges for the $21^{\text {st }}$ Century, edited by K.S. Nathan, Mohammad Hashim Kamali, Singapore: Institute of Southeast Asian Studies, 2005, hlm. 33.

4 Ahmad Haris, "The Haramayn and Its Historic Function: A Source of Religious Tradition and Reform", Innovatio, 5.10 (Julai-Disember 2006): hlm. 394.

$5 \quad$ Abdullah Ishak, Islam di Nusantara (Khususnya Di Tanah Melayu), Kuala Lumpur: Bahagian Hal Ehwal Islam, Jabatan Perdana Menteri, 1992, hlm. 104. 
$6 \quad$ Ibid., hlm. 104; Hashim Musa, Merekonstruksi Tamadun Melayu Islam: Ke Arah Pembinaan Sebuah Tamadun Dunia Alaf Ketiga, Kuala Lumpur: Akademi Pengajian Melayu, 2001, hlm. 53.

7 Raja Ali Haji, Tuhfat al-Nafis, Dikaji dan diperkenalkan oleh Virginia Matheson Hooker, Kuala Lumpur: Yayasan Karyawan dan Dewan Bahasa dan Pustaka, 1998, hlm. 3.

$8 \quad$ Khalif Muammar A. Harris, "Ilmu Ketatanegaraan Melayu Abad ke-19: Kajian Terhadap Karya Raja Ali Haji”, Sari - International Journal of the Malay World and Civilisation 29.1 (2011): hlm.79-101.

9 Syeikh Abdul Samad Al-Palembani dilahirkan pada 1116 H/1704 M, di Palembang. Sejarah mencatatkan tiga versi nama yang lengkap bagi Syeikh Al-Palimbani. Ensiklopedia Islam mencatatkan nama beliau sebagai Abdus Samad Al-Jawi Al-Palembani. Manakala berdasarkan sumber-sumber Melayu, Azyumardi Azra menyatakan bahawa nama asli beliau ialah Abdul Samad bin Abdullah Al-Jawi Al-Palembani. Sementara itu, apabila merujuk kepada sumber-sumber Arab, nama lengkap Syeikh Al-Palembani ialah Sayyid Abdus Al-Samad bin Abdurrahman AlJawi. Daripada penelitian terhadap ketiga-tiga sumber nama tersebut, Azyumardi berpendapat bahawa nama terakhir tersebut merupakan nama sebenar Syeikh Abdul Samad. Lihat, Azyumardi Azra, The Origins of Islamic Reformism in Southeast Asia: Networks of Malay-Indonesian and Middle Eastern 'Ulama' in the Seventeenth and Eighteenth Centuries, Crows Nest, Australia: Allen \& Unwin, 2004, hlm. 52 -53.

Kebanyakan ulama Nusantara dikenali kerana pengetahuan Ilmu tasawwuf mereka yang mendalam antaranya, Syeikh Abdul Samad al-Palimbani, Hamzah Fansuri, Shamsuddin al-Sumaterani, Nuruddin al-Raniri, Abdul Rauf al-Singkel, Daud al-Fattani, Yusuf al-Makassari, Mohd Nafis al-Banjari, Tok Kenali, Tok Pulau Manis dan lain-lain. Syed Mohd Naquib al-Attas juga menyatakan wujudnya pelbagai gerakan tarekat seperti, Ahmadiyyah, Qadiriyyah, Naqsabandiah, Shattariyah, Rifa'iyyah, Khalwatiyyah, Christiyyah, Samaniyah, Shadiliyyah dan lain-lain yang menguatkan hujah bahawa terdapat kecenderungan yang kuat dalam kalangan orang Melayu untuk mengalami ilmu tasawwuf. Lihat Mohd Syukri Yeoh Abdullah, Ahmad Redzuwan Mohd Yunus, "Tasawwuf: An Impetus to Islamic Revivalism in the Malay World", Tawarikh: International Journal for Historical Studies, 2.2 (2011): hlm.178, 175-190; Syed Mohd Naquib al-Attas, Some Aspect of Sufism as Understood and Practiced among the Malays, Singapore: MSRI LTD, 1963, hlm. 22.

11 "Syeikh Abdul Samad Al-Palembani: Dari Nusantara ke Tanah Arab, Kuala Lumpur: Yayasan Dakwah Islamiyah Malaysia, 28 Oktober 2004, hlm. 1-2; Suhaila Abdullah, Mohd Sukki Othman, "Peranan dan Sumbangan Ulama' 'Tiga Serangkai' dalam Perkembangan Islam dan Transformasi Sosial di Malaysia", Prosiding Nadwah Ulama Nusantara (NUN) IV: Ulama Pemacu Transformasi Negara, Bangi, Selangor: Universiti Kebangsaan Malaysia, 2011, hlm. 443-445.

12 Suhaila Abdullah, Mohd Sukki Othman, "Peranan dan Sumbangan Ulama', hlm. 443-446. 
13 Shukri Ahmad, Ismail Yusoff, Hamzah, "Pendekatan Dakwah Ulama Sufi Nusantara Abad ke-17M dan 18M: Suatu Analisis Perbandingan dengan Pendekatan Dakwah Ulama Malaysia Abad ke-21, Prosiding Nadwah Ulama Nusantara (NUN) IV: Ulama Pemacu Transformasi Negara, Bangi, Selangor: Universiti Kebangsaan Malaysia, 2011, hlm. 428.

14 Abdul Karim Amrullah; Tokoh Pembaharuan Minangkabau, Radio Online: Pagarak, 25 Mei, 2012. http:/ / radiopagarak.blogspot.com/2012/05/abdulkarim-amrullah-tokoh-pembaharuan.html. (Tarikh dicapai pada $26 \mathrm{Mei}$ 2012).

15 Arba'iyah Mohd Noor, “Perkembangan Pensejarahan Islam Di Alam Melayu", Jurnal al-Tamaddun, 6: 2011: hlm. 29-50.

16 Mohamad Zulkifli Abdul Ghani, Norazam Nordin, Abdul Ghafar Don \& Adawiyyah Ismail, "Sumbangan Syeikh Mohamed Idris Al-Marbawi dalam Dakwah Islamiyyah di Malaysia", Prosiding Nadwah Ulama Nusantara (NUN) V: Ulama dan Cabaran Idealisme Semasa 2013, 9-10 September 2013, hlm. 110.

17 Rahimin Affandi Abd. Rahim, "Citra Islam Dalam Pembentukan Manusia Melayu Moden di Malaysia: Suatu Analisa", Jurnal Pengajian Melayu, 15: 2005: hlm. 20-21.

18 Lihat Wan Mohd Nor Wan Daud, Penjelasan Budaya Ilmu, Kuala Lumpur: Dewan Bahasa dan Pustaka, 1997, hlm. 108-109; B.J.O. Schrieke, Indonesian Sosiological Studies, The Hague, 1957, Part 2, hlm. 261; Abdul Rahman Abdullah, Pemikiran Umat Islam Di Nusantara, Kuala Lumpur: DBP, 1990, hm. 127-130.

19 Abd Jalil bin Borham, "Tulisan Jawi: Tulisan Serantau", Kertas kerja Ucaptama Seminar Tulisan Jawi dan Teknologi Peringkat Kebangsaaan 2012 di Dewan Astaka, Universiti Malaysia Pahang, 18 Oktober 2012, hlm. $5-6$.

$20 \quad$ Nabir Abdullah, "Turki Dan Alam Melayu: Tinjauan Terhadap Sejarah Hubungan Keduanya"', Jebat, Bil. 15, 1987: hlm. 129- 142; Abd. Jalil Borhan, "Sumbangan Ulama Dalam Perkembangan Islam Di Alam Melayu", Jurnal Syariah, Vol. 4, Bil. 2, 1996, hlm. 278.

21 Persekitaran politik amat mempengaruhi kebangkitan semula Islam di kedua-dua negara. Dengan majoriti penduduknya yang menganut agama Islam menjadikan pengaruh agama tersebut semakin kukuh dalam struktur masyarakat dan politik negara. Lihat, "Fred R. von der Mehden, "Malaysia and Indonesia", dalam Hunter, Shireen T., The Politics of Islamic Revivivalism, Bloomington and Indianapolis: Indiana University Press, 1988, hlm. 247-248.

22 Pengenalan sekolah Inggeris yang berbentuk sekular di Selangor dan Kuala Lumpur telah menyebabkan orang Melayu bimbang mengenai matlamat dan niat pihak British untuk mengkristiankan orang Melayu. Pada peringkat permulaan, sekolah Inggeris telah menerima sambutan yang dingin dan tidak mendapat sokongan daripada pelajar-pelajar Melayu. Bagi ibu bapa Melayu, mereka menyamakan kedudukan pendidikan British dengan agama Kristian dan mereka tidak menunjukkan minat untuk menghantar anak-anak mereka ke sekolah ini. Selain itu, dilaporkan 
bahawa terdapat berita yang telah tersebar dalam kalangan penduduk kampung di Sabak Bernam, Selangor mengatakan bahawa mubaligh Kristian sanat aktif menyebarkan agama mereka kepada orang Melayu. Penduduk Sabak Bernam yang bimbang dengan berita tersebut mula memikirkan pendidikan agama untuk anak-anak mereka. Di samping itu, penurunan subjek pendidikan Islam di sekolah-sekolah Melayu pada tahun 1930-an turut menyumbang kepada keputusan mereka untuk menubuhkan sekolah Arab atau madrasah. Ryan, N.J. "The Malay College, 1905-1963", Malaysia in History, Vol. VIII, No. 2, 1964, hlm. 26; Md. Jani Naim. "Sekolah Agama Rakyat di Sabak Bernam hingga 1945", dalam Islam in Malaysia, Kuala Lumpur: Penerbit Persatuan Sejarah Malaysia, 1979, hlm. 55.

Mohammad Redzuan Othman, Islam dan Masyarakat Melayu: Peranan dan Pengaruh Timur Tengah, Kuala Lumpur: Penerbit Universiti Malaya, 2005, hlm. 110-111.

Menurut al-Imam, bertarikh 8 Oktober 1907, madrasah ini diumumkan pembukaannya pada 21 November 1907 oleh akhbar tersebut. (alImam, Jilid 2, No. 4, 8 Oktober 1907, hlm. 122). Namun begitu, bukti yang ada menunjukkan bahawa madrasah ini dibuka pada 4 Februari 1908. Lihat Mohd. Sarim Haji Mustajab, "Islam dan Perkembangannya dalam Masyarakat Tanah Melayu, 1900-1940an", Tesis M.A., Universiti Kebangsaan Malaysia, 1975, hlm. 356; Lihat juga Al-Imam, Jilid 2, No. 8, 4 Februari 1908, hlm. 264.

Madrasah al-Hadi yang diasaskan pada tahun 1917 didapati gagal mendapat sambutan yang menggalakkan daripada masyarakat dan terpaksa ditutup. Walau bagaimanapun, Sayyid Syeikh al-Hadi lebih berjaya apabila mengasaskan Madrasah al-Mashhor di Pulau Pinang pada tahun 1919. Lihat Rahim Osman, "Madrasah Masyhur al-Islamiyah", dalam Khoo Kay Kim, et al., Islam di Malaysia, Kuala Lumpur: Persatuan Sejarah Malaysia, 1980, hlm. 75-85. Mohammad Redzuan Othman, Islam dan Masyarakat Melayu, hlm. 115. Syeikh Tahir dilahirkan di Kota Tua, Ampek Angkek, di Tanah Minangkabau Sumatera pada 4 Ramadhan 1286 bersamaan 7 Disember 1869. Beliau merupakan seorang yang berketurunan bangsawan dan ulama Melayu Minangkabau. Ketika berumur sebelas tahun, Syeikh Tahir telah dihantar oleh keluarganya menuntut ilmu di Makkah. Beliau kemudiannya menyambung pengajiannya di Universiti al-Azhar dari tahun 1895 hingga tahun 1897. Selepas itu beliau kembali semula ke Makkah dan tinggal di sana sehingga tahun 1899. Syeikh Tahir tidak pulang ke Minangkabau, tetapi ke Perak menetap dan berumahtangga di sana. Syeikh Tahir dilantik sebagai Ahli Mesyuarat Orang-Orang Besar Perak dan dilantik sebagai Mufti Negeri Perak. Sumbangan beliau amat besar dalam membina kesedaran masyarakat Melayu terhadap agama dengan terbitnya majalah al-Imam. Sila rujuk Abdul Aziz Mat Aton, Politik Al-Imam, Kuala Lumpur: Dewan Bahasa dan Pustaka, 2001, hlm 159-166; Zainon Ahmad, "The Life, Times, and Thoughts of Sayyid Syeikh Ahmad al-Hadi", M.A. Thesis, University of Malaya, 1974, hlm. 10-11; Abdul 
Aziz Mat Ton, "Gerakan Asarul Sunnah Dalam kegiatan Kaum Muda Di Melaka", Tesis B.A. Universiti Malaya, 1972/73, hlm. 18.

Kheang, Cheah Boon., Red Star Over Malaya: Resistance and Social Conflict During and After The Japanese Occupation, 1941-1946, Singapore: Singapore University Press, 2003, hlm. 11; Siddiq Fadzil, "Jaringan Amal Islami di Alam Melayu: Menusuri Jejak Pengaruh Da'i Indonesia di Malaysia", Seminar Pra Silaturrahim Nasional (Silatnas) Dewan Da'wah Islamiyyah Indonesia (DDII) - Dewan Da'wah dan Pendidikan di Jakarta pada 25 September 2010, hlm. 2.

Sejak tahun 1970-an, Malaysia dan Indonesia mencatatkan perkembangan dan kecenderungan usaha dakwah yang amat ketara selari dengan perkembangan kebangkitan semula Islam di negara-negara Islam yang lain. Lihat, Endang Saifuddin Anshari, "Dunia Islam: Masa Lalu dan Kini Menyongsong Abad XV Hijrah", dalam Kebangkitan Islam Dalam Perbahasan, Rusydi Hamka dan Iqbal Emsyarip A.S. (ed.), Bandung: Yayasan Nurul Islam, 1979, hlm. 33-34.

Anwar Ibrahim, Presiden ABIM ke 2. Ucapan Dasar ke 10, "Membina Generasi - Satu Gagasan", di Dewan Tunku Cancelor Universiti Malaya, Kuala Lumpur, 9 Ogos 1981.

Angkatan Belia Islam Malaysia (ABIM) di Malaysia banyak menimba pengalaman dan cetusan pemikiran daripada tokoh-tokoh ilmuan dan pemikir era kebangkitan semula Islam Indonesia, khususnya Mohamad Natsir atau Pak Natsir, Dr Imaduddin dan Hamka. Selain mengamati tulisan dan pemikiran mereka tentang Islam dalam masyarakat, ABIM turut mengadakan hubungan yang baik dengan tokoh-tokoh tersebut. ABIM juga turut mengambil inisiatif menganalisis pemikiran mereka, sebagai contoh, pandangan Pak Natsir dalam pendidikan Islam yang dimuatkan dalam Jurnal Pendidikan Islam terbitan Institut Pengajian Ilmu-Ilmu Islam IPI-ABIM keluaran Jun 1999. Keterangan lanjut tentang pendidikan Islam oleh Mohamad Natsir, hubungan dan penglibatan ABIM dengan Dr Imaduddin dan Hamka, lihat Mohammad Noer, "Ideologi Pendidikan Islam Mohamad Natsir", Jurnal Pendidikan Islam, Jilid 8, Bil. 3 (Jun 1999): hlm. 1-31; Zainah Anwar, Kebangkitan Islam di Kalangan Pelajar, Petaling Jaya: IBS Sdn. Bhd., 1990, hlm. 45-46. ABIM, WADAH dan PKPIM juga telah menganjurkan Seminar Pemikiran Dakwah \& Perjuangan Buya Hamka yang diadakan di Kolej Dar Al-Hikmah, Kajang, Selangor pada 28 Mei 2014 sempena mengingati jasa dan sumbangan pemikiran beliau dalam mengaplikasikan Islam dalam konteks sosiobudaya Melayu di Nusantara.

32 Pengerusi Jawatankuasa Biro Antarabangsa ABIM sesi 2011-2012, Jufitri Joha melaporkan bahawa ABIM terus memperkukuhkan hubungannya dengan Dewan Dakwah dengan mengadakan Mesyuarat Teknikal Memperkukuhkan Hubungan ABIM dan dewan Dakwah yang dipengerusikan oleh Presiden ABIM pada 28 Februari 2012. Lihat Laporan Tahunan ABIM 2011/2012, Muktamar Sanawi Angkatan Belia Islam Malaysia (ABIM) ke-41, di Auditorium Abu Zarim, ILSAS-UNITEN \& Kolej Dar Al-Hikmah, pada 29-30 September 2012, hlm. 51. 
33 Lihat kenyataan Anwar Ibrahim. "Natsir, Politikus Intelektual", Tempo, 14 Julai 2008; Siddiq Fadzil, "Jaringan Amal Islami di Alam Melayu", hlm. 4.

34 Lihat, Natsir, M. Capita Selecta, Jakarta: Bulan Bintang, 1955, Cetakan Ketiga, 1973. hlm. 3-15.

35 Siddiq Fadzil, "Mengenang Pak Natsir", 14 November 2008. http:// khairaummah.com/index2.php?option=com_content\&do_ pdf $=1 \& i d=265$. Dicapai pada 27 Jun 2012. Muhammad Nur Manuty, “Bapak Mohamad Natsir: Sosok Peribadi Da'i Teladan", Seminar Serantau Memperingati 100 Tahun Pahlawan Nasional Bapak Mohammad Natsir, 10 Januari 2009, hlm. 2.

A. M. Fatwa, "Natsir, Dakwah, Politik" dalam Lokman Hakiem (ed.), 100 Tahun Mohammad Natsir - Berdamai Dengan Sejarah, Jakarta: Penerbit Republika, 2008, hlm. 413; Muhammad Nur Manuty, "Bapak Mohamad Natsir: Sosok Peribadi Da'i Teladan", Seminar Serantau Memperingati 100 Tahun Pahlawan Nasional Bapak Mohammad Natsir, 10 Januari 2009, hlm. 3.

Siddiq Fadil, "Demokrasi: Aspirasi dan Realiti", Seminar Demokrasi di Malaysia: Aspirasi dan Realiti, Anjuran WADAH, di Esset KWSP, Kajang Selangor, pada 4 Ogos 2007, hlm. 7. Ibid., hlm. 1-7.

Pak Natsir menyarankan penyatuan dua golongan intelektual umat Islam iaitu, antara golongan ulamak dan intelektual, sehingga wujudnya tradisi intelektual-ulama dan ulamak-intelektual dalam DDII yang memberi tumpuan kepada pendekatan dakwah dan pendidikan. Sementara itu, Dato' Siddiq Fadzil ketika memberikan ucapan dasarnya di Muktamar Sanawi ABIM ke-13 menyentuh keutamaan dakwah dan pendidikan seperti berikut: "Untuk menambah keberkesanan dakwah khususnya dalam menghadapi persoalan-persoalan dan cabaran-cabaran semasa, para dai' tidak harus statis - membeku di takuk lama. Sesungguhnya cabaran yang dihadapi oleh para du'ah zaman ini yang berupa faham kebendaan dari Barat dengan segala cabang dan alirannya itu tidak akan dapat dijawab dengan berkesan kecuali dengan menguasai ilmu-ilmu tentang fahaman itu". Lihat Natsir, M., Capita Selecta, Jakarta: Bulan Bintang, 1955, Cetakan Ketiga, 1973. hlm. 3-15; ABIM: 1971-1996 25 Tahun, Kuala Lumpur: Angkatan Belia Islam Malaysia, 1996, hlm. 90.

$41 \quad$ Pak Natsir menyarankan agar ABIM membantu memperkukuhkan PAS dengan memberikan "blood infusion"kepada PAS. Berikutan saranan tersebut, seramai tiga orang ahli Jawatankuasa ABIM Pusat telah memasuki PAS menjelang Pilihan Raya Umum pada tahun 1978. Mereka ialah Ustaz Fadhil Noor, Timbalan Presiden ABIM, Ustaz Nakhaei Ahmad, Ketua Dakwah dan Saudara Syed Ibrahim Syed Abdul Rahman, Penasihat Undang-Undang ABIM. Menurut pandangan Pemangku Presiden ABIM pada ketika itu, iaitu Siddiq Fadhil, kemasukan Anwar ke dalam politik kepartian tidak menjejaskan ABIM sebagai sebuah gerakan Islam yang berjuang menegakkan Islam menerusi dakwah dan tarbiyah. Ahli-ahli ABIM tetap optimis dalam meneruskan perjuangannya berdasarkan 
prinsip dan nilai-nilai yang dibinanya selama satu dekad yang lalu. Lihat kenyataan akhbar, Kamaruddin Jaffar, "ABIM Tegaskan Sikap", Risalah, Bil. 2, 1982, hlm. 1, 2; Riduan Mohamad Nor, Menerjang Badai: 60 Tahun Mempersada Perjuangan, Kuala Lumpur: Jundi Resources, 2011, hlm. 38. Lihat Anwar Harjono, Pemikiran dan Perjuangan Mohammad Natsir, Jakarta: Pustaka Firdaus, 2001, hlm. 5-7; Endang Saifuddin Anshari dan Rais M. Amien, Pak Natsir 80 Tahun Buku Pertama Pandangan dan Penilaian Generasi Muda, Jakarta: Media Dakwah, 1988, hlm. 25.

43 Siti Hamisah Manan, Gelombang Kebangkitan Dakwah Kampus, Kuala Lumpur: JIMedia, 2009, hlm. 58-60; Siddiq Fadzil, “Jaringan Amal Islami di Alam Melayu: Menusuri Jejak Pengaruh Da'i Indonesia di Malaysia”, Seminar Pra Silaturrahim Nasional (Silatnas) Dewan Da'wah Islamiyyah Indonesia (DDII) - Dewan Da'wah dan Pendidikan, Jakarta, 25 September 2010, hlm. 7.

44 Buku Cenderamata Sempena Persidangan Agong Tahunan yang ke XI PKPIM, 30 Julai - 5 Ogos 1972, hlm. 12; Zainah Anwar, Islamic Revivalism in Malaysia: Dakwah Among the Students, Petaling Jaya: Pelanduk Publications, 1987, hlm. 46-47.

45 Siddiq Fadzil, "Jaringan Amal Islami di Alam Melayu”, hlm. 2. Rumaizuddin Ghazali, "Hamka Namamu Tetap Abadi", Minda Madani Online, 12 Jun 2012. "Hamka yang Sederhana", Utusan Melayu, 12 Jun 2012. Tafsir Hamka telah dijadikan bahan sokongan dan rujukan dalam sukatan tarbiah JIM dan PAS. Lihat Modul 1-Modul 8, Sukatan Usrah dan Tarbiah JIM dalam Panduan Pembangunan Insan dan Organisasi JIM, Kuala Lumpur: Pertubuhan Jamaah Islah Malaysia, 2002, hlm. 9-19; Yahya Haji Othman, Usrah Sebagai Tunjang Tarbiyah Gerakan Islam Dakwah Wajib Bagi Seorang Mukmin, Kota Bharu: Pustaka Aman Press Sd. Bhd., 2012; Manhaj Usrah PAS Peringkat Ta'rif 2, Kuala Lumpur: Lajnah Tarbiah dan Perkaderan PAS Pusat. 2009, hlm. 135.

49 Program yang diatur adalah dalam bentuk seminar, ceramah, latihan kepimpinan dan pertemuan di antara PKPIM dan ABIM dari Malaysia dengan Himpunan Mahasiswa Islam (HMI), tokoh Institut Teknologi Bandung, seperti Dr Imaduddin dan pertemuan serta hubungan akrab ABIM-Pak Natsir. Temuramah bersama Prof. Dr. Razali Nawawi pada 10 Mei 2012 di Bandar Baru Bangi, Selangor.

50 Konstitusi Himpunan Mahasiswa Islam, Jakarta: Universal Press, September 2009. hlm. 3; M. Chozin Amirullah. Sejarah HMI dari Zaman Kemerdekaan Sampai Reformasi. t.t.: t.p. 2011, hlm. 1-25. http://www.pbhmi.net/ images/stories/download/Sejarah-HMI-dari-Zaman-KemerdekaanSampai-Reformasi. Dicapai pada 23 Jun 2012; Al-Mandari, S. HMI dan Wacana Revolusi Sosial. Ujung Pandang: Pusat Studi Paradigma Ilmu (PSPI), 1999, hlm. 4-15; Awalil Riezky, HMI (MPO) Dalam Transisi, Jogjakarta: Pengurus Besar Himpunan Mahasiswa Islam, 2006. hlm. 5-10. Temuramah bersama Prof. Dr. Razali Nawawi pada 10 Mei 2012 di Bandar Baru Bangi, Selangor.

52 Zainah Anwar, Islamic Revivalism in Malaysia, hlm. 46. 
Temubual penulis bersama Prof. Dr. Razali Nawawi pada 10 Mei 2012, 9.59 am di Akademi Quran-Medik Malaysia, Bandar Baru Bangi, Selangor. Temubual penulis bersama Prof. Dr. Razali Nawawi pada 10 Mei 2012. Zainah Anwar, Islamic Revivalism in Malaysia, hlm. 33.

Raleigh, Elizabeth., "Busana Muslim dan Kebudayaan Populer di Indonesia: Pengaruh dan Persepsi", Laporan Kajian, Universitas Muhammadiyah Malang, Indonesia, 2004, hlm. 45-46.

Nazaruddin Shahari, "Industri Nasyid Keluar dari Kepompong", Utusan Melayu, 7 Julai 2008, hlm. 2.

Ibid., hlm. 2.

Ibid., hlm. 1-2.

Utusan Melayu, 7 Julai 2008, hlm. 2.

Farihad Shalla Mahmud, "Festival lagu Islam di KLCC", Berita Harian, 29 Mac 2011.

Alamsyah Agus, "Bagaimana Perkembangan Nasyid Indonesia", Bogor Nasheed Centre, 2 Mac 2011, hlm. 1-2.

Ibid., hlm. 1-2.

Sekitar tahun 1999 hingga tahun 2002, kebanyakan kumpulan nasyid di Indonesia dipengaruhi oleh identiti dan corak persembahan Raihan dengan menggunakan hanya iringan musik perkusi minimalis dan berbahasa Melayu. Bagi melonjak industri nasyid di Indonesia dan menarik minat masyarakat terhadap irama berbentuk keagamaan, pihak menganjur terpaksa bersusah payah menjemput satu kumpulan nasyid yang didatangkan khas dari Malaysia dengan perbelanjaan yang bukan sedikit dalam penganjuran sesebuah pertunjukan nasyid. Sedangkan dengan perbelanjangan yang sama dapat membiayai lebih daripada satu kumpulan nasyid tempatan dengan kualiti yang tidak banyak perbezaannya. Irama nasyid yang dibawa dari Malaysia, khususnya kumpulan Raihan sangat mudah diterima oleh masyarakat Indonesia atas faktor persamaan budaya dan bahasa serumpun dengan identiti Melayu-Islamnya tersendiri. Namun begitu, selepas tahun 2002 berlaku perubahan dalam industri nasyid di Indonesia dari segi mengetengahkan alat muzik dan genre nasyid yang pelbagai. Lihat Ahmad Mustaqim, "Media Komunikasi Visual Sebagai Penunjang Promosi Nasyid Zukhruf", Thesis M.A. Seni Rupa Jurusan Desain Komunikasi Visual Fakultas Sastra dan Seni Rupa, Universitas Sebelas Maret Surakarta, 2006, hlm. 1-4.

"Sekilas Tentang Musik Nasyid",17 Jun 2012, PasarKreasi.com. http:// www.pasarkreasi.com. Dicapai pada 18 Jun 2012.

Alamsyah Agus, "Bagaimana Perkembangan Nasyid Indonesia”, hlm. 3.

"Kumpulan Nasyid Sufi Beraksi di Indonesia", Utusan Melayu, 19 September 2009.

Muhammad Nur Manuty, “Bapak Mohamad Natsir: Sosok Peribadi Da'i Teladan", hlm. 2.

Anuar Tahir, "Menjalin Hubungan Antara Bangsa: Sebuah Catatan Pengalaman", dalam Angkatan Belia Islam Malaysia: 1971-1996, Petaling Jaya: Angkatan Belia Islam Malaysia (ABIM), 1996, hlm. 52-53. 
70 Antara kota yang terkenal di Indonesia dan menjadi tumpuan penggemar fesyen tudung dan busana Muslimah dalam kalangan Kelas Menengah Melayu Muslim dari Malaysia ialah Bandung, Jakarta, Surabaya dan Yogyakarta. Sila rujuk, Ahmad Sunawari Long, "Impak Kebangkitan Semula Islam Terhadap Pengamalan dan Penghayatan Agama Kelas Menengah Melayu Muslim Malaysia: Kajian Kes di Lembah Klang", Thesis PhD,University of Malaya, 2010, hlm. 300; Wulandari, Sri. "Peranan Komunikasi Dalam Meningkatkan Efektivitas Kerja Pada PT. Shafira Laras Persada Cabang Medan", Thesis B.A., Fakultas Ekonomi, Universitas Sumatera Utara, Medan, 2014, hlm. 8-9.

71 Menurut Ahmad Mustaqim, perkembangan awal nasyid di Indonesia bermula sejak tahun 1990. Pengaruh kumpulan nasyid dari Malaysia seperti Nadamurni, The Zikr dan Raihan serta kumpulan nasyid dari Palestin amat ketara pada peringkat awal perkembangan industri nasyid Indonesia. Ini dapat dilihat melalui pembentukan identiti dalam menampilkan nasyid dan corak persembahan kumpulan Izzatul Islam dan Snada. Kemunculan kumpulan Raihan di Malaysia berjaya menambat hati peminat dan meningkatkan pertumbuhan industri nasyid di Indonesia. Walaupun hingga tahun 2002, kebanyakan kumpulan nasyid di Indonesia dipengaruhi oleh identiti dan corak persembahan Raihan, namun sejak tahun 2002, corak nasyid Indonesia mengalami perubahan yang ketara apabila alat muzik seperti kobor, drum dan gitar digunakan. Perubahan juga berlaku apabila kebanyakan kumpulan nasyid yang membawa idealisme masing-masing mula mempersembahkan genre nasyid baru seperti pop, acapella, akustik, jazz, orchestra, world music, R n B, country, rap dan hip hop. Ahmad Mustaqim, "Media Komunikasi Visual Sebagai Penunjang Promosi Nasyid Zukhruf", hlm. 1-4. 